\title{
Reproductive periods and larval abundance patterns of the crabs Panopeus africanus and Uca tangeri in a shallow inlet (SW Spain)
}

\author{
A. Rodríguez, P. Drake*, A. M. Arias \\ Instituto de Ciencias Marinas de Andalucía (CSIC), E-11510 Puerto Real, Cádiz, Spain
}

\begin{abstract}
Adult females of Panopeus africanus A. Milne Edwards, 1867 and Uca tangeri (Eydoux, 1835) were sampled fortnightly from April 1989 to November 1991 in the Rio San Pedro inlet (SW Spain) to estimate the seasonal timing of their reproductive periods. Planktonic larvae were collected monthly from July 1991 to June 1992 by pumping during nocturnal flood and ebb spring tides to establish seasonal larval abundance patterns. Additional $24 \mathrm{~h}$ series of samples were collected in July 1991 and May/June 1992 to analyse larval abundance in relation to the main environmental cycles (diel, tidal and lunar phases, and vertical position in the water column). Both species showed a short, latespring/summer reproductive period: mature and ovigerous females peaked from May to July. Seasonal occurrences of first zoea larvae also indicated short reproductive periods for both species. First zoea was the most abundant stage, representing $99.5 \%$ (P. africanus) and $99.9 \%$ (U. tangeri) of all individuals collected. On most sampling occasions, there was a net output of zoea I of both species from the inlet, suggesting that larvae are released in the inlet and exported to the bay. The abundance of the first zoea of $P$. africanus was higher durng high and ebb tides, at night and at the surface of the water column. For this species, there was a significant interaction between lunar phase and diel phase: zoea l were most abundant during nocturnal neap tides. Zoea I of $U$. tangeri showed greater density at ebb tides; they were more abundant at the surface of the water column during ebb than at high tide, suggesting a vertical migration between these tidal phases. Considerable short-term (consecutive or alternate days) and long-term (interannual) variation in the abundance of larvae was observed for both species. The comparison of our results with the scarce information available on the reproductive periods and larval patterns of both species suggests that, at the northern limit of their latitudinal ranges, water temperature may control the seasonal timing of reproductive periods, but populations under different hydrodynamic regimes (different water conditions) might show peaks of larval release during different diel/tidal/lunar phases; this association of larval release with rhythmic cues may serve as a mechanısm that may aid escape of larvae from unsuitable environmental conditions.
\end{abstract}

KEY WORDS: Panopeus africanus - Uca tangers Reproductive period Larval stages Abundance patterns Hatching rhythms

\section{INTRODUCTION}

Panopeus africanus is a common crab on the southwestern coast of the Iberian Peninsula, where it is usually found burrowed in mud, under stones or among oyster shells in estuaries and other shallow tidal ecosystems. It is endemic and the only representative of the genus on the eastern Atlantic coasts,

\footnotetext{
•E-mail:pilar.drake@icman.csic.es
}

where it has a wide geographical distribution from Portugal to Angola (Manning \& Holthuis 1981). The Afro-European fiddler crab Uca tangeri is also endemic to the eastern Atlantic and has a similar distribution, from the Iberian Peninsula to southern Angola; records of its occurrence in America seem to be erroneous (Manning \& Holthuis 1981). The latter species is found exclusively burrowed in mud, muddy sand or sandy areas of shallow coastal ecosystems. In the Rio San Pedro inlet of SW Spain, the 2 species show slightly different spatial distribution: $P$. africanus 
usually inhabits the mid- and low-intertidal areas (mainly under stones), while $U$. tangen burrows are mainly constructed in the high-intertidal zone near the small tidal creeks which are distributed laterally along the main inlet channel).

The complete larval development of both species has recently been described (Rodríguez \& Jones 1993, Rodriguez \& Paula 1993). Previous references on the larval development of these species are very scarce (Feest 1969, Paula 1985). The only available information about the larval abundance and rhythms of Panopeus africanus and Uca tangeri is from populations of the Mira Estuary on the southwestern Portuguese coast (Paula 1989, 1993). There is also limited information on their reproductive periods (Feest 1969, Manning \& Holthuis 1981, Müller 1983). Therefore, it remains unclear whether seasonal abundance of the first zoeal stage in the water column reflects seasonal larval release by females and/or larval survival rates.

Both species are among the most abundant macrobenthic crustacean inhabitants of the Rio San Pedro inlet. This inlet was originally a part of the Guadalete River estuary, but sedimentary processes and human activity together have changed it into a marine tidal inlet. Despite these hydrodynamic changes, the ecosystem persists in performing an important role as a nursery area in the early life of marine fish species (Drake \& Arias 1991). Yet, there is very little known about the use of the inlet by larvae and postlarvae of macrobenthic species such as brachyuran crabs. Furthermore, the only information available about the reproductive cycle and larval abundance rhythms of the crabs Panopeus africanus and Uca tangeri is from typical estuarine systems (Müller 1983, Paula 1989, 1993). Thus, we studied the reproductive period and the larval abundance pattern of these 2 species in a shallow tidal inlet, where the freshwater inflow is insignificant.

\section{MATERIALS AND METHODS}

Study site. This study was carried out in Rio San Pedro, a shallow inlet of the saltmarsh zone situated to the east and south of the Bay of Cádiz $\left(36^{\circ} 23^{\prime}-37^{\prime} \mathrm{N}\right.$, $6^{\circ} 8^{\prime}-15^{\prime} \mathrm{W}$ ). This sinuous, $12 \mathrm{~km}$ long inlet, characterized by semidiurnal mesotides (tidal range 1 to $3.5 \mathrm{~m}$ ) and a soft muddy bed, crosses the northeastern part of the salt marsh and terminates in the middle east shore of the bay (Fig. 1). The tidal current from the bay flows along the inlet, whose freshwater inflow is insignificant except during heavy rains, and supplies sea water to some saltmarsh fish ponds situated on both sides of the channel.

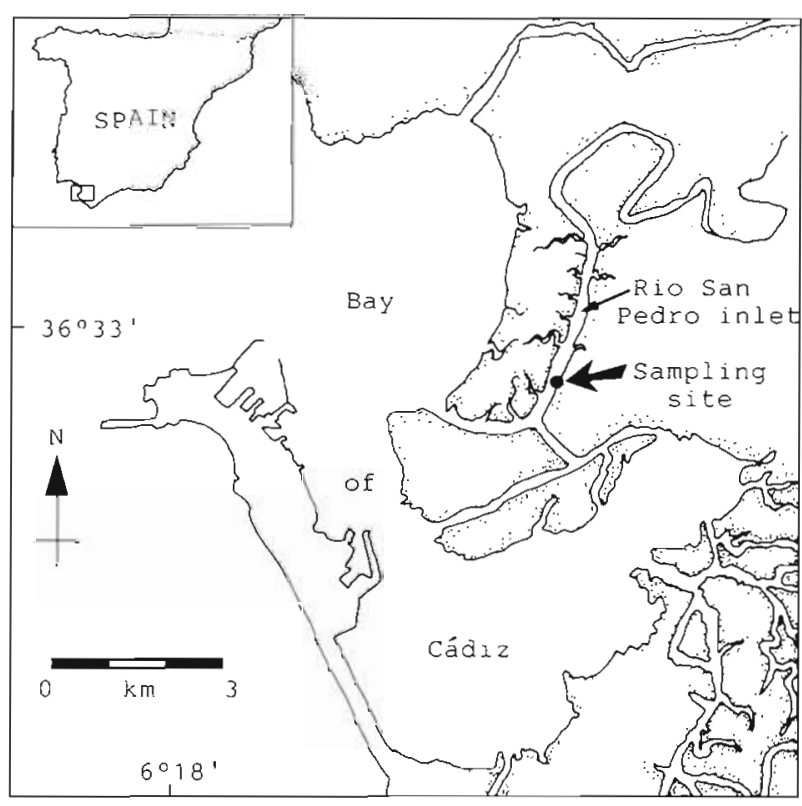

Fig. 1. Location of the sampling site in the Bay of Cadiz, SW Spain.

The sampling site was located $3 \mathrm{~km}$ from the inlet mouth, where the channel width was approximately $200 \mathrm{~m}$ during high spring tides, and at a point situated $50 \mathrm{~m}$ from the water's edge, where the channel bottom was $1.28 \mathrm{~m}$ below hydrographic zero. There the inlet cross-section showed a continuously submerged central channel (mean depth $=1.44 \mathrm{~m}$ below hydrographic zero; $\mathrm{SD}=0.99 \mathrm{~m}$ ), and lateral tidal flats partially exposed at low tides (mean depth $=2.19 \mathrm{~m}$ above hydrographic zero; $\mathrm{SD}=0.99 \mathrm{~m}$ ).

Sampling. Adult females of $U_{C a}$ tangeri ( $\mathrm{n}=999$; carapace length $>15 \mathrm{~mm}$ ) and Panopeus africanus $(\mathrm{n}=1098$ carapace length $>11 \mathrm{~mm}$ ) were collected fortnightly (at spring tides) during most of the sampling period, from April 1989 to August 1990 and from August 1990 to November 1991, respectively, in the Rio San Pedro inlet. A random subsample of 25 females (or total sample if $n<25$ ) for each sample were measured (carapace length, $C L$ ) and weighed (wet weight, $W$ ). Ovaries were removed and weighed (wet weight, OW). Females were classified into 1 of 3 gonadal development stages using ovary gross morphology (size, colour, turgidity) as criteria and ovigerous females were considered to be a fourth reproductive stage; thus, the stages were: I, immature; II, maturing; III, mature; $\Gamma$, ovigerous females. In addition, gonadal development was estimated by calculating the gonadosomatic index $(\%$, GI) according to the formula:

$$
\mathrm{GI}=(\mathrm{OW} / \mathrm{W}) \times 100
$$

Individual fecundity, as egg production relative to body size, was estimated by counting the total number of eggs of the ovigerous females. 
To estimate the annual patterns of larval abundance of Panopeus africanus and Uca tangeri, crab larvae were collected from July 1991 to June 1992. Samples were taken monthly during the night hours of spring tides. Each sampling consisted of 2 pumpings, lasting $1 \mathrm{~h}$ each ( $30 \mathrm{~min}$ at $0.5 \mathrm{~m}$ below the surface and $30 \mathrm{~min}$ at $0.5 \mathrm{~m}$ above the bottom); pumping began $4 \mathrm{~h}$ before (flood) and $3 \mathrm{~h}$ after (ebb) the expected time of high water, and was performed a gasoline-powered impeller pump whose outflow was filtered through a $300 \mathrm{\mu m}$ mesh. The pump outflow was calibrated before each sampling period and kept approximately constant for all samples, so that each 30 min pumping period allowed the filtration of 10 to $12 \mathrm{~m}^{3}$ of water. To establish the patterns of larval stages in relation to diel, tidal and lunar cycles, as well as vertical position in the water column, additional samples were collected in July 1991 and May-June 1992. During each sampling period, four 24 h series ( 2 spring and 2 neap tides) of 8 samples, lasting 1 h each $(30 \mathrm{~min}$ at $0.5 \mathrm{~m}$ below the surface and $30 \mathrm{~min}$ at $0.5 \mathrm{~m}$ above the bottom), were taken at $3 \mathrm{~h}$ intervals in synchronization with tidal phases (at each diurnal/nocturnal high, ebb, low and flood tides), in order to obtain 2 samples for each diel, tidal and lunar situation, and for vertical position in the water column. Samples were preserved immediately in $5 \%$ formaldehyde. Larvae were categorized by zoeal stages ( 4 and 5 zoeal stages for $P$. africanus and $U$. tangeri, respectively) and megalopal stages ( 1 megalopa for each species) and sorted by species (Rodríguez \& Jones 1993, Rodríguez \& Paula 1993).

Data analysis. The number of crab larvae caught in every 30 min pumping period was adjusted to obtain a bundance per $10 \mathrm{~m}^{3}$ of filtered water. Larval abundance was $\log (x+1)$ transformed prior to analysis to decorrelate the mean and variance. For each species, a 5-way ANOVA was performed to test the effect of diel (D), tidal (T) and lunar cycles (L) on the larval abundance, as well as the larval vertical position in the water column (P) and interannual variation of larval abundance $(\mathrm{Y})$. Only second-order interactions of these factors were analyzed.

Hydrological measurements. Water temperature and salinity were measured at the start of each pump sampling. Additional weekly measurements of both variables were supplied by the Centro de Investigación y Cultivo de Especies Marinas 'El Toruno' (Fig. 2). During each $24 \mathrm{~h}$ series, data on current speed were also obtained hourly with a Hydrobios current meter.

\section{RESULTS}

\section{Reproductive period}

The reproductive cycles of Panopeus africanus and Uca tangeri were reflected by changes in the gonado-
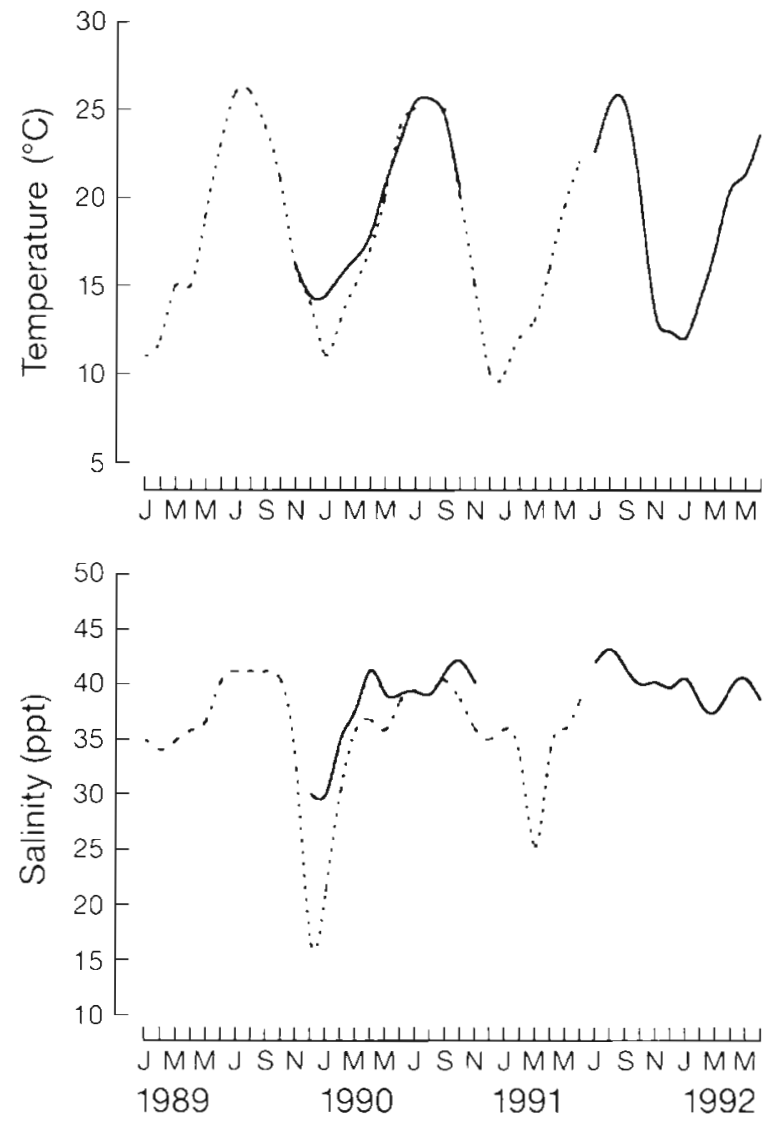

Fig. 2. Seasonal changes in water temperature $\left({ }^{\circ} \mathrm{C}\right)$ and salinity $(\%)$ during the sampling period at the Rio San Pedro inlet. Continuous line: hydrological data recorded monthly during this study; dotted line: hydrological data (weekly) supplied by the Centro de lnvestigaciones y Cultivo de Especies Marinas 'El Toruño'

somatic index of females throughout the year (Fig. 3). In both species the principal period of female gonad development (gonadal weight $>2 \%$ body weight) occurred from May to July. The presence of stage III (mature) and IV (ovigerous) females peaked during this period of high GI values. Conversely, immature and regressed gonads were generally small and resulted in a low GI (August to March). During the period of maximal gonad development (GI $>2 \%$ ), there was no significant correlation $(\mathrm{p}>0.05)$ between GI and female size $(P$. africanus: $\mathrm{r}=-0.146, \mathrm{n}=58 ; U$. tangeri $\mathrm{r}=-0.103, \mathrm{n}=201$ ).

Total number of eggs per female ranged from 1100 (carapace length $=12.2 \mathrm{~mm}$ ) to $62200(26.4 \mathrm{~mm})$ for Panopeus africanus, and from $9300(15 \mathrm{~mm})$ to 77100 $(24 \mathrm{~mm})$ for Uca tangeri. Individual fecundity (egg production), estimated from ovigerous females, was significantly correlated with female size $(p<0.01)$. Thus, in the studied population, individual egg production (EP) of $P$. africanus and $U$. tangeri females can be 
estimated as a function of size (CL, carapace length in $\mathrm{mm})$, using the following regression equations:

$P$ africanus: $\mathrm{EP}=5.757 \mathrm{CL}^{2829}(\mathrm{r}=0.858 ; \mathrm{n}=134)$

U. tangeri: $\quad \mathrm{EP}=3.450 \mathrm{CL}^{2.985}(\mathrm{r}=0.825 ; \mathrm{n}=84)$
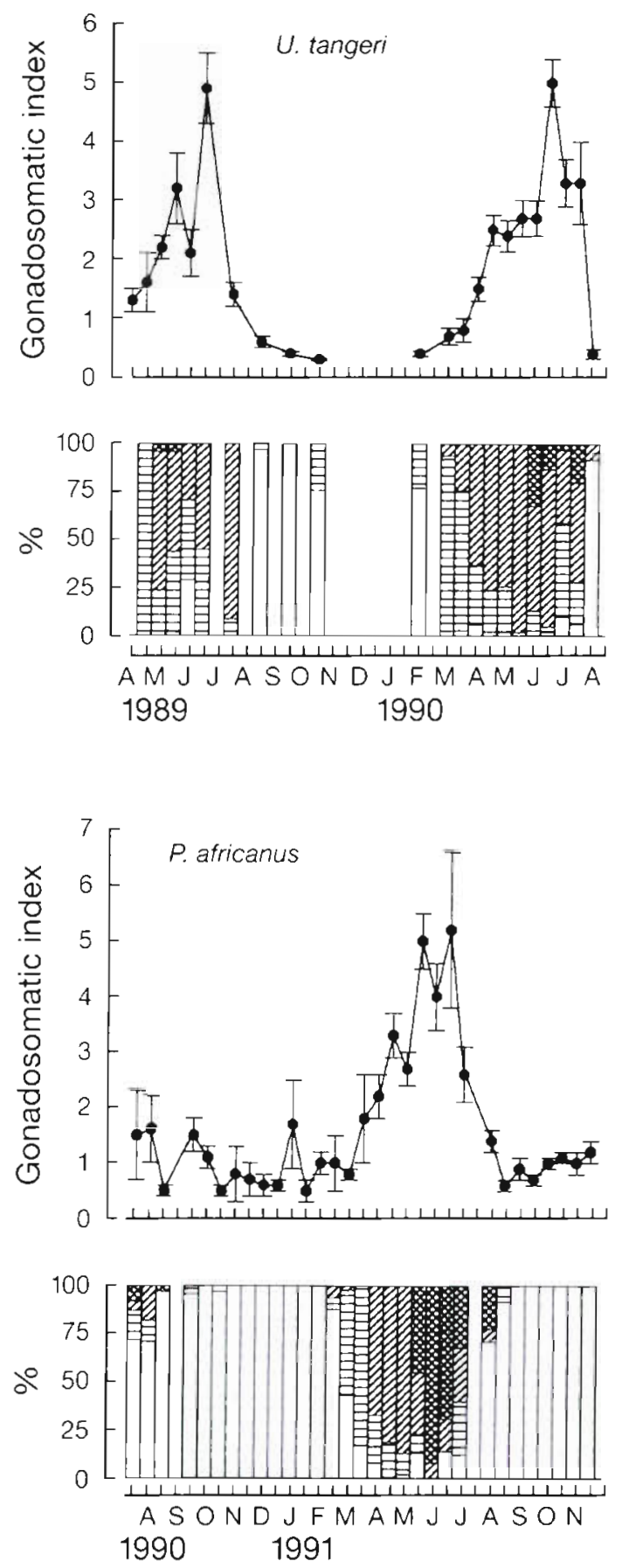

Fig. 3. Fortnightly gonadosomatic index (\%) and proportion of Panopeus africanus and Uca tangeri females in the different gonadal development stages: ( $\square$ ) I immature, (日) II maturing, (घ) III mature, ( IV ovigerous females

\section{Larval stage composition}

A total of 2603 and 4271 individuals (zoeae and megalopaej of Panopeus africanus and Uca tangeri, respectively, were collected during the study period. Zoea I larvae were predominant, representing $99.5 \%$ ( $P$. africanus) and $99.9 \%$ ( $U$. tanger $)$ of all individuals collected. Zoea stages II to IV were rarely ( $P$. africanus $0.2 \%$ ) or never (U. tangeri) collected (Table 1$)$. The megalopal stage was scarce as well $10.3 \%$ for $P$. africanus; $0.1 \%$ for $U$. tangeri)

\section{Seasonal larval abundance}

Zoea I of Panopeus africanus and Uca tangeri were present from late May to November and September, respectively, and both species showed maximal larval abundance in August 1991 and in late June 1992 (Fig. 4). Taking the different current speed and larval density at the surface and bottom of the water column into account, we estimated the input (flood) and output (ebb) of larval crabs at the study inlet as the number of individuals passing every hour through a $1 \mathrm{~m}^{2}$ crosssection of the inlet. At most sampling occasions, there was a net output of zoea I of both species from the inner part of the inlet to the bay (Fig. 4).

\section{Diel and tidal patterns of larval abundance}

The abundance of first zoeae of Panopeus africanus and Uca tangeri, together with hydrological data for the study inlet, within each $24 \mathrm{~h}$ series is shown in Figs. 5 (July 1991) and 6 (May-June 1992). Results of 5-way ANOVA on the abundance of $P$. africanus zoea I (Table 2) indicated that larvae of this species were more abundant during high and ebb tides, suggesting that they are released in the inlet and exported to the bay. In fact, the flux (see 'Seasonal larval abundance' above) of zoea I within each 24 h series indicated a net

Table 1. Number of zoea II to IV and megalopa of Panopeus africanus and Uca tangeri caught during the study period at the Rio San Pedro inlet

\begin{tabular}{|c|c|c|c|c|c|c|}
\hline & $\begin{array}{l}\text { Zoea } \\
\text { II-IV }\end{array}$ & $\begin{array}{l}\text { Mega- } \\
\text { lopa }\end{array}$ & date ${ }^{\text {Sam }}$ & $\begin{array}{l}\text { ple charac } \\
\text { position }\end{array}$ & $\begin{array}{l}\text { teristics: } \\
\text { light }\end{array}$ & tide \\
\hline $\begin{array}{l}\text { Panopeus } \\
\text { africanus }\end{array}$ & $\begin{array}{l}1 \\
1 \\
3\end{array}$ & $\begin{array}{l}1 \\
8\end{array}$ & $\begin{array}{l}12 \text { Jul } 1991 \\
12 \text { Jul } 1991 \\
10 \text { Aug } 1991 \\
9 \text { Sep } 1991 \\
\text { 29 Jun } 1992\end{array}$ & $\begin{array}{l}\text { bottom } \\
\text { surface } \\
\text { bottom } \\
\text { surface } \\
\text { surface }\end{array}$ & $\begin{array}{l}\text { day } \\
\text { night } \\
\text { night } \\
\text { night } \\
\text { night }\end{array}$ & $\begin{array}{l}\text { low } \\
\text { low } \\
\text { flood } \\
\text { flood } \\
\text { flood }\end{array}$ \\
\hline $\begin{array}{l}\text { Uca } \\
\text { tangeri }\end{array}$ & & $\begin{array}{l}1 \\
2\end{array}$ & $\begin{array}{l}12 \text { Jul } 1991 \\
10 \text { Aug } 1991\end{array}$ & $\begin{array}{l}\text { surface } \\
\text { bottom }\end{array}$ & $\begin{array}{l}\text { day } \\
\text { night }\end{array}$ & $\begin{array}{l}\text { ebb } \\
\text { flood }\end{array}$ \\
\hline
\end{tabular}



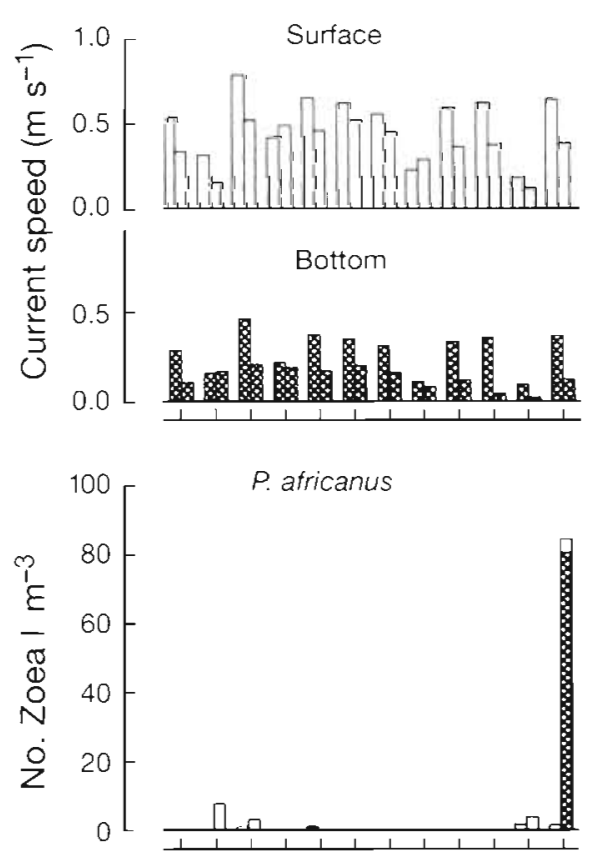

Fig. 4. Monthly current speed $\left(\mathrm{m} \mathrm{s}^{-1}\right)$, larval density (no. zoea $\mathrm{l} \mathrm{m}^{-3}$ ) and larval flux (no. zoea $\mathrm{I} \mathrm{m}^{-2} \mathrm{~h}^{-1}$ ) of Panopeus africanus and Uca tangeri in the Rio San Pedro inlet. For each month, bars on the left and right of the tick mark correspond to the flood and ebb values, respectively; the shaded part of each bar represents individuals that were caught close to the bottom

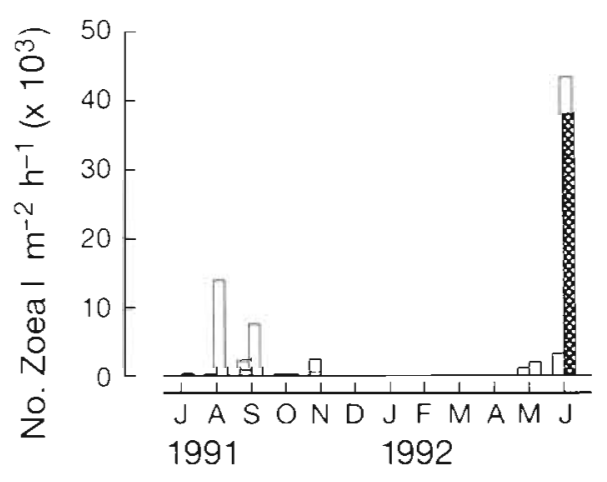

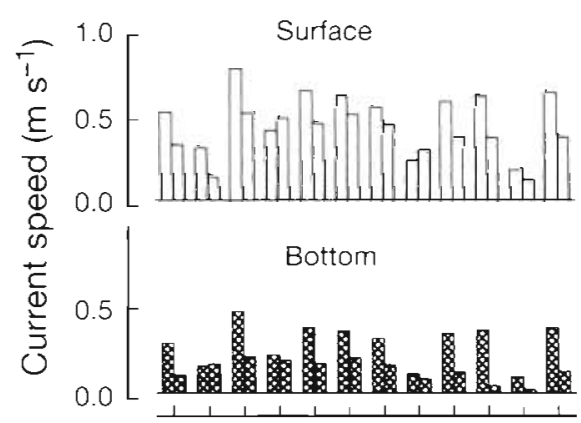
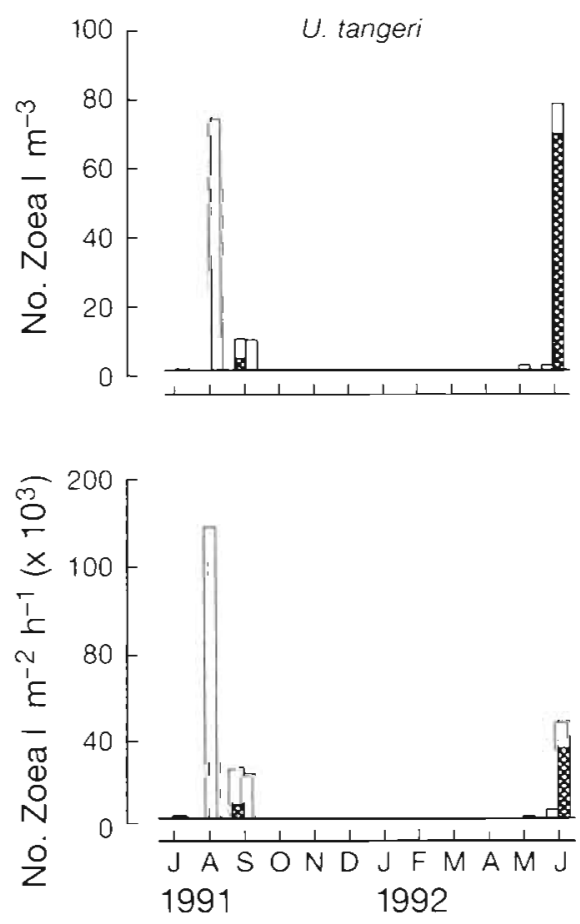

output for 7 of the 8 series. Larvae were also more abundant at night than during the day, and at the surface of the water column than on the bottom. In addition, there was a significant interaction between lunar phase and diel phase: zoea I were significantly more abundant during nocturnal neap tides. When zoea I abundance data were expressed, for each diel/tidal situation, as a percentage of total number caught during each $24 \mathrm{~h}$ series to eliminate the often considerably short-term (between consecutive or alternate days) and long-term (between years) variation (see Figs. 5 \& 6), a significant ( 2 -way ANOVA; $p<0.01$ ) interaction effect between diel/tidal and lunar phases emerged for $P$. africanus; during spring tides there were no statistically significant differences in larval abundance between the nocturnal and diurnal tidal cycles, but such differences were significant during neap tides (Fig. 7). On the other hand, zoea $I$ of $U$. tangeri showed higher density at ebb tide, again suggesting larval export from the inlet to the bay (Table 2).
The flux of zoea I indicated a net input to the inlet for only one of the $24 \mathrm{~h}$ series. For this species, the tidal phase vs vertical position interactions were found to be significant: larval density at the surface of the water column is higher during ebb tide than during high tide. Significant differences in abundance between samples from the neap tides of 1991 and 1992 were also observed. Conversely to $P$. africanus, after short- and long-term differences had been accounted for, there was no significant difference in $U$. tangeri abundance between nocturnal and diurnal tidal cycles vs lunar phases (2-way ANOVA; $p>0.05$ ), and maximal mean relative abundance occurred during both nocturnal and diurnal ebb tides (Fig. 7). Finally, significant interannual differences of zoea I abundance were found for both species.

No significant correlation between larval abundance of either species and hydrological variables (current speed, water temperature and salinity) was observed ( $p>0.05$ ) within any of the 24 h series. 

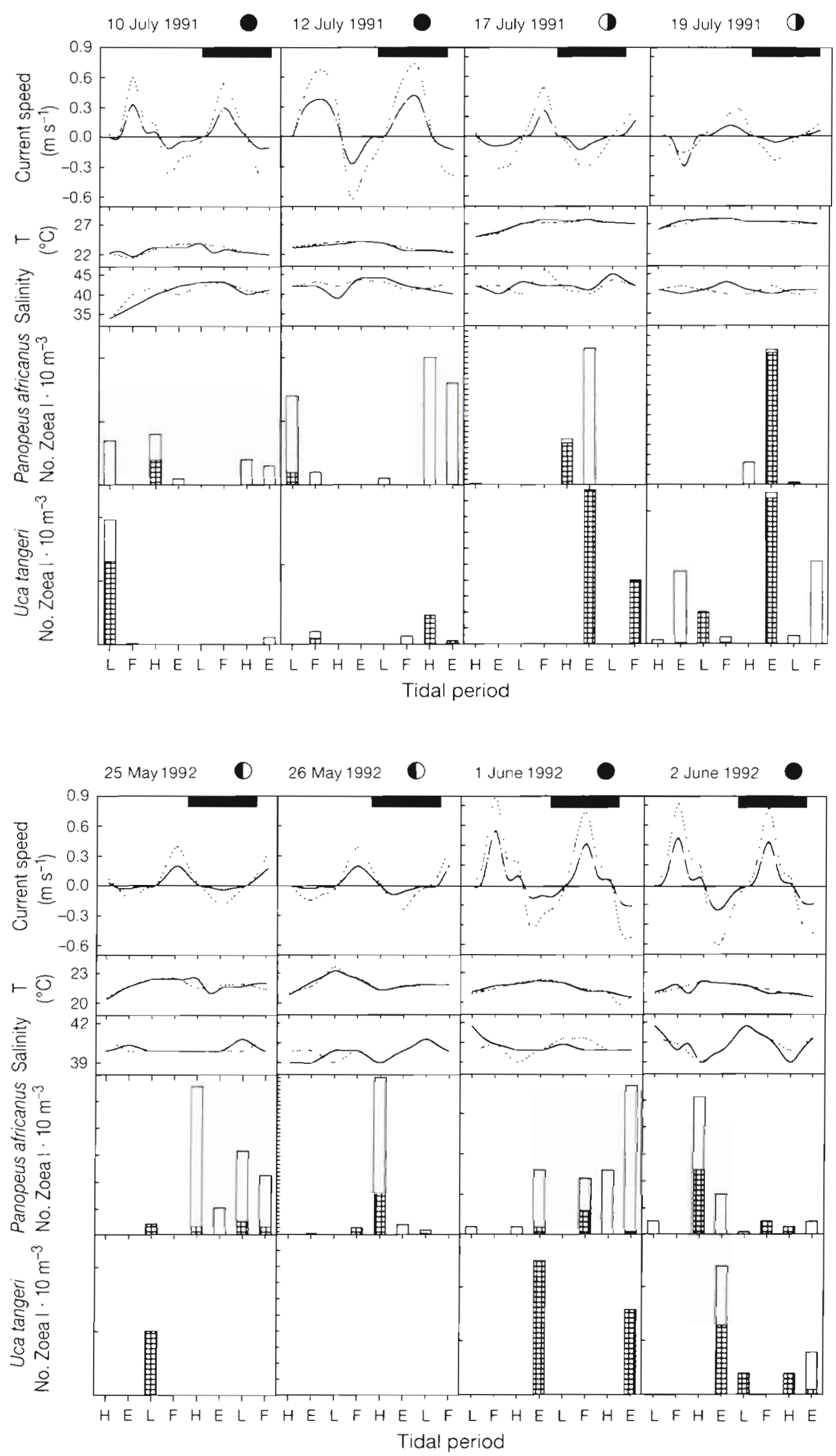

Fig. 5. Diel/tidal variation in water current speed, temperature (T), salinity (\%) and density of zoea I of Panopeus africanus and Uca tangeri in the Rio San Pedro inlet from $24 \mathrm{~h}$ sampling series in July 1991. H, high tide; $E$, ebb tide; L, low tide; $F$, flood tide. New moon and quarter moon are indicated by closed and half-filled circles, respectively. Filled bars on the top indicate nighttime. Continuous and dotted lines show hydrological data for the bottom and the surface of the water column, respectively. The shaded part of each vert1cal bar represents individuals that were caught close to the bottom

Fig. 6. Diel/tidal variation in water current speed, temperature (T), salinity $(\%)$ and density of zoea I of Panopeus africanus and Uca tangen in the Rio San Pedro inlet from 24 h sampling series in MayJune 1992. Tidal phases, symbols and further details as in Fig. 5 legend 
Table 2. Results of 5-way ANOVA comparing the effects of year, tidal phase, lunar phase, diel phase and vertical position on the abundance (log-transformed data) of Panopeus africanus and Uca tangeri zoea I at the Rio San Pedro inlet. Mean zoeal densities under the conditions joined by an underline were not signuficantly different at the $5 \%$ level using Student-Newman-Keuls test. df: degrees of freedom; MS: mean square; p: significance level; F: flood; E: ebb; L: low tide; $\mathrm{H}$ : high tide; $\mathrm{D}$ : daytime; $\mathrm{N}$ : nighttime; $\mathrm{Sp}$ : spring tide; $\mathrm{Np}$ : neap tide; S: surface; B: bottom

\begin{tabular}{|c|c|c|c|c|}
\hline & $\mathrm{df}$ & MS & $\mathrm{p}$ & Student-Newman-Keuls test \\
\hline \multicolumn{5}{|l|}{ P. africanus } \\
\hline \multicolumn{5}{|l|}{ Main effects } \\
\hline Year, Y & 1 & 12.0 & 0.00 & $1991<1992$ \\
\hline Tidal phase, $T$ & 3 & 6.6 & 0.00 & $\mathrm{~F}<\mathrm{L}<\mathrm{E}<\mathrm{H}$ \\
\hline Lunar phase, L & 1 & 3.0 & 0.15 & \\
\hline Diel phase, D & 1 & 12.8 & 0.00 & $\mathrm{D}<\mathrm{N}$ \\
\hline Vertical position, $\mathrm{P}$ & P 1 & 15.1 & 0.00 & $B<S$ \\
\hline \multicolumn{5}{|l|}{ Interactions } \\
\hline $\mathrm{Y} \times \mathrm{T}$ & 3 & 0.9 & 0.59 & \\
\hline$Y \times L$ & 1 & 0.2 & 0.69 & \\
\hline$Y \times D$ & 1 & 2.0 & 0.24 & \\
\hline $\mathrm{Y} \times \mathrm{P}$ & 1 & 0.0 & 0.90 & \\
\hline $\mathrm{T} \times \mathrm{L}$ & 3 & 0.6 & 0.75 & \\
\hline$T \times D$ & 3 & 1.2 & 0.48 & \\
\hline$T \times P$ & 3 & 2.8 & 0.12 & \\
\hline$L \times D$ & 1 & 15.0 & 0.00 & $N p D<S p N<S p D<N p N$ \\
\hline$L \times P$ & 1 & 2.1 & 0.22 & \\
\hline $\mathrm{D} \times \mathrm{P}$ & 1 & 2.1 & 0.23 & \\
\hline Residual & 102 & 1.4 & & \\
\hline \multicolumn{5}{|l|}{ U. tangeri } \\
\hline \multicolumn{5}{|l|}{ Main effects } \\
\hline Year, Y & 1 & 15.3 & 0.00 & $1992<1991$ \\
\hline Tidal phase, $T$ & 3 & 4.3 & 0.04 & $\mathrm{H}<\mathrm{L}<\mathrm{F}<\mathrm{E}$ \\
\hline Lunar phase, L & 1 & 0.8 & 0.48 & $S p<N p$ \\
\hline Diel phase, D & 1 & 1.4 & 0.35 & \\
\hline Vertical position, $\mathrm{P}$ & $\mathrm{P} 1$ & 0.9 & 0.46 & \\
\hline \multicolumn{5}{|c|}{ Interactions } \\
\hline $\mathrm{Y} \times \mathrm{T}$ & 3 & 1.1 & 0.55 & \\
\hline$Y \times L$ & 1 & 9.4 & 0.01 & $1992 N p<1992 S p<1991 S p<1991 N p$ \\
\hline $\mathrm{Y} \times \mathrm{D}$ & 1 & 3.0 & 0.16 & \\
\hline$Y \times P$ & 1 & 0.4 & 0.63 & \\
\hline$T \times L$ & 3 & 0.7 & 0.69 & \\
\hline $\mathrm{T} \times \mathrm{D}$ & 3 & 2.2 & 0.23 & \\
\hline $\mathrm{T} \times \mathrm{P}$ & 3 & 3.8 & 0.05 & $\mathrm{HS}<\mathrm{HB}<\mathrm{LS}<\mathrm{FB}<\mathrm{EB}<\mathrm{LB}<\mathrm{FS}<\mathrm{ES}$ \\
\hline$L \times D$ & 1 & 1.7 & 0.29 & \\
\hline$L \times P$ & 1 & 0.0 & 0.95 & \\
\hline $\mathrm{D} \times \mathrm{P}$ & 1 & 0.1 & 0.82 & \\
\hline Residual & 102 & 1.5 & & \\
\hline
\end{tabular}

$>2 \%$ was only found for water temperatures higher than $20^{\circ} \mathrm{C}$ (Figs. $2 \& 3$ ). Consequently, zoea I of both species were present in the plankton when water temperatures were elevated (20 to $25^{\circ} \mathrm{C}$ ). Paula (1993) found a similar relationship between water temperature and first larval presence in the Mira Estuary. He indicated that the survival of zoea I of $P$. africanus is very low at water temperatures below $20^{\circ} \mathrm{C}$. In addition, $U$. tangeri needs sediment surface temperatures higher than $18^{\circ} \mathrm{C}$ to be active at the surface (Wolfrath 1992) and, consequently, during cool months (November to March in the study latitude) crabs stay in their burrows (Müller 1983). During the sampling period, it was not possible to catch $U$. tangeri females between late October and February (Fig. 3). Thus, the reproductive cycles of $P$. africanus and $U$. tangeri appear to be closely linked to seasonal temperature, with short breeding periods (in the warmest months), at least for the populations studied, which are near the northern limit of their latitudinal ranges. In contrast, the breeding seasons of African populations are longer, and ovigerous $P$. africanus females have been observed in January, March, April, July and November on the western inter-tropical coast of Africa (Manning \& Holthuis 1981). Water salinity, as previously observed by Paula (1993) for first larval stage abundance, did not seem to affect the seasonal timing of the reproductive cycles of either species.

The first zoeal stage of both species studied was generally more abundant during the ebb phase (Figs. 4, 5 \& 6),

\section{DISCUSSION}

In the study inlet, the seasonal presence of mature and ovigerous Panopeus africanus and Uca tangeri females showing a high gonadosomatic index coincided quite well with peaks of first zoeal stage abundance. Unfortunately, the sampling years for adult females and plankton larval abundance did not completely coincide in this study. Nevertheless, the results suggest that seasonal abundance of first zoeae in the water column reflects the magnitude of larval release by females. For $P$. africanus and $U$. tangeri females, GI indicating larval export from the Rio San Pedro inlet to the Bay of Cádiz. Rapid export of first zoeae out of estuaries has been previously reported for several crab species (Dittel \& Epifanio 1990, Dittel et al. 1991, Queiroga et al. 1994, Zeng \& Naylor 1996). This fate was observed for Uca tangeri in the Mira Estuary, while a retention of Panopeus africanus larvae within the estuary was found in the same system (Paula 1993). But the latter species showed maximal larval survival (zoea I to megalopa) for a water salinity of $25 \mathrm{ppt}$ (Paula 1993). This salinity may be found within typical estuaries even during the summer. However, in the 

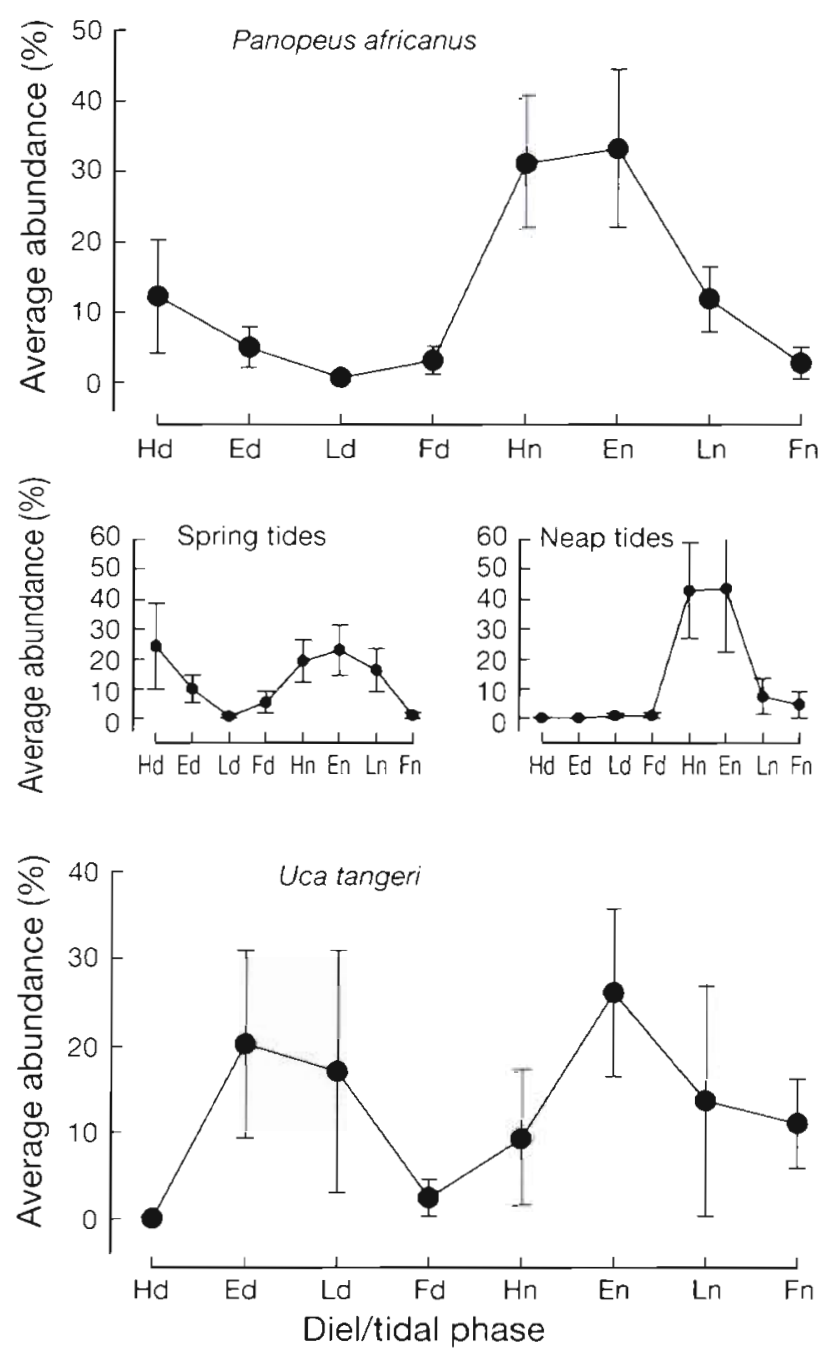

Fig. 7. Average proportion of zoea l of Panopeus africanus and Uca tangeri collected in the $24 \mathrm{~h}$ series that were caught at each diel/tidal phase. $\mathrm{Hd}$, diurnal high tide; Ed, diurnal ebb tide; Ld, diurnal low tide; Fd, diurnal flood tide ${ }_{i}$ Hn, nocturnal high tide; En, nocturnal ebb tide; Ln, nocturnal low tide; Fn, nocturnal flood tide

inlet studied, salinity during the reproductive period of $P$. africanus was about $40 \mathrm{ppt}$ (Fig. 2). Thus, there may be selective pressure acting on females to facilitate larval export and to escape unsuitable high water salinity within the study inlet. In crab species whose larvae are exported, most of the larval development takes place in the sea, and megalopae are the stage that reinvades the parental population habitat (Christy 1989, Little \& Epifanio 1991). A means of rapid megalopal immigration into estuaries is to swim with the current during flood tides and to rest on the bottom at other tidal phases (Little \& Epifanio 1991). But fiddler crab megalopae seem to be able to settle and metamorphose very early in development if they encounter suitable sediment (Christy 1989). Furthermore, juve- nile and adult crabs also are capable of considerable movements, and recruitment to estuarine crab populations may occur through immigration of juveniles and adults of the species considered (Sandifer 1975). So, a possible hypothesis to explain the low abundance of megalopae observed in this study is that, due to the situation of the study inlet within the Bay of Cádiz (Fig. 1), most megalopae immigrating from the sea settle on the mud flats which surround the mouth of the inlet, and the $P$. africanus and $U$. tangeri populations are restocked mainly by immigration of juveniles or adults from outside the inlet. Müller (1983) also found a very low number of returning megalopae of $U$. tangeri in the Guadalquivir estuary. Another possible explanation could be that the sampling method used (pumping) was unsuitable for catching advanced larval stages, though this seems very unlikely because this method has successfully caught megalopae in previous studies (Dittel \& Epifanio 1990, Queiroga et al. 1994). Nevertheless, Wehrtmann \& Dittel (1990) found $U_{c a}$ sp. megalopae which were attached to drifting leaves, using them as a transport mechanism to reinvade estuaries in mangrove areas. Larval and juvenile crabs might have been attached to floating macroalgae in our study inlet, which would have reduced the probability of their being caught. A final explanation of the low number of megalopae in our samples may be that they were imported when sampling was not occurring.

The bathymetric characteristics of the inlet studied classify it as a shallow flood-dominated system, where the hydrodynamic regime could facilitate the passive retention of planktonic larvae (Drake \& Arias 1991). Under such conditions, to be exported, (1) larvae may synchronize their activity, and/or (2) females may synchronize the larval release, with the most suitable tidal phases (high and ebb tides). The first strategy may be accomplished by endogenously controlled, tidally rhythmic vertical migration of larvae (Cronin \& Forward 1979, Zeng \& Naylor 1996); for exportation, larvae should stay near surface during ebb tides and close to the bottom during floods. But in the present study the tidal phase vs vertical position interaction effect was not significant for Panopeus africanus first zoea abundance, indicating the absence of tidal vertical migration. However, this interaction had a significant effect on Uca tangeri zoea I abundance (Table 2), with a significantly lower density at the surface during high tide than during ebb tide; but such vertical migration alone does would not explain the high level of exportation observed for the species. The second mechanism, tidal synchronization of female release of larvae, seems to be a more probable cause of exportation of $P$. africanus and $U$. tangeri larvae at the studied inlet. In fact, the observed patterns of first zoea abun- 
dance of $P$. africanus (significantly greater during high and ebb tides) and of $U$. tangeri (more abundant at ebb tides) (Figs. 5 \& 6) probably reflected larval hatching activity.

Larval release near the time of high tide and at night is common among brachyurans living in tidal areas (DeCoursey 1983, Forward 1987, De Vries \& Forward 1991), and it seems to be the pattern for the studied population of Panopeus africanus, with a higher first zoea abundance occurring generally at high and ebb tides and at night (Table 2). In the Mira Estuary, Paula (1993) also found that the abundance of $P$. africanus first zoeae was greater during nighttime, but with maximal values at late ebb tides. Although a similar pattern of larval release has been indicated for several species of fiddler crabs (DeCoursey 1979, Bergin 1981. De Vries \& Forward 1991), there were no significant differences between daytime and nighttime abundance of Uca tangeri zoea I in this study, and maximal density was mainly observed at ebb tides (Table 2). The latter fact has also been observed for this species by Paula (1993) in the Mira Estuary. On the other hand, it has been previously suggested that the importance of release after darkness may increase with increasing elevation of the adult habitat: predation pressure on females releasing larvae during the day may increase for species inhabiting higher intertidal habitats (De Vries \& Forward 1989). But results of the present study are not in agreement with this suggestion. the mid- to low-intertidal crab $P$. africanus showed higher zaea I density during nighttime, while the high-intertidal crab $U$. tangeri did not show such nighttime/daytime differences. In the study inlet, the observed timing of first zoea abundance suggests that both species synchronize larval release with the tidal phase at which their respective habitats are flooded. Such a pattern of larval release has been previously observed for other species of intertidal crabs (Morgan \& Christy 1995). Under this assumption, predation on adult females and hatching larvae by visually-hunting aquatic predators may be more probable for $P$. africanus, the species inhabiting the lower tidal habitat. Furthermore, a different predation pressure on both egg-bearing females and newly hatched larvae could also explain why we observed a different diel/tidal lunar-phase-dependent abundance of first zoeae for $P$. africanus but not for $U$. tangeri (Fig. 7): during neap tides, when slower currents cause lower water turbidity, the importance of release after darkness may increase.

Peaks of larval release for intertidal crabs have often been correlated with the moon phases and local diel/ tidal cycles. In fact, Salmon et al. (1986) observed maximal first zoea density of Panopeus herbstii and Uca spp. during spring tides in the Newport River Estuary (tidal amplitude 0.7 to $1.3 \mathrm{~m}$ ). Their results also suggested that fiddler crab larval release responds to tidal amplitude and not to the time interval between high tide and the onset of darkness. On a small sandy beach with tidal amplitudes between 0.1 and $0.7 \mathrm{~m}$ (from Fig. 2 in Christy 1978), a peak of Uca pugilator females releasing their larvae at neap tides was observed. Conversely, Paula (1989) found that the amplitude of tides ( 1 to $2.8 \mathrm{~m}$ in the Mira Estuary) did not seem to control larval release of a European population of UCa tangeri, and any crepuscular high tide seemed to be suitable for larval release. The latter author also indicated that there was no obvious semi-lunar pattern of Panopeus africanus larval release in the Mira Estuary. Results of the present study suggest that there were no clear differences of larval release between spring and neap tides for either species in the studied system. The considerable differences in tidal amplitude between these American and European habitats may contribute to the different way in which this factor influences the larval release of their respective crab populations. Moreover, different diel/tidal patterns of larval release of $P$. africanus seem to exist in the study inlet depending on lunar phase, with 2 diel peaks at spring tides but just 1 nocturnal peak at neap tides. However, due to the considerable short-term variation in larval abundance, longer sampling periods will be needed before we can be more conclusive concerning this topic.

In addition to the short- (between consecutive or alternate days) and long-term (interannual) variation in the abundance of zoea I of both species, there was a significant interaction effect of lunar phase vs year on Uca tangeri first zoea abundance: maximal and minimal values were observed for 1991 and 1992 neap tides, respectively (Table 2 ). But these results may be related to the fact that the breeding season had not reached its full peak in late May of 1992, when neap tide samples were taken.

Acknowledgements. This research was supported financially by Junta de Andalucia and Consejo Superior de Investigaciones Científicas. We are grateful to $\mathrm{M}$. Espigares and $\mathrm{S}$. González for their invaluable help in sorting samples and the Centro de Investigaciones y Cultivo de Especies Marinas 'El Toruno' (Consejería de Agricultura y Pesca) for providing hydrological data.

\section{LITERATURE CITED}

Bergin ME (1981) Hatching rhythms in Uca pugilator (Decapoda: Brachyura). Mar Biol 63:151-158

Christy JH (1978) Adaptive significance of reproductive cycles in the fiddler crab Uca pugilator. a hypothesis. Science 199:453-455

Christy JH (1989) Rapid development of megalopae of the fiddler crab Uca pugilator reared over sediment: implications for models of larval recruitment. Mar Ecol Prog 
Ser 57:259-265

Cronin TW, Forward RB (1979) Tidal vertical migration: an endogenous rhythm in estuarine crab larvae. Science 205:1020-1022

DeCoursey PJ (1979) Egg-hatching rhythms in three species of fiddler crabs. In: Naylor E, Hartnoll RG (eds) Cyclic phenomena in marine plants and animals. Pergamon Press, Oxford, p 399-406

DeCoursey PJ (1983) Biological timing. In: Bliss D, Vernberg EJ, Vernberg WB (eds) The biology of crustacea, Vol 7 Academic Press, New York, p 107-162

De Vries MC, Forward RB Jr (1989) Rhythms in larval release of the sublittoral crab Neopanope sayi and the supralittoral crab Sesarma cinereum (Decapoda: Brachyura). Mar Biol 100:241-248

De Vries MC, Forward RB Jr (1991) Control of egg-hatching in crabs from different tidal heights. J Crustacean Biol 11. $29-39$

Dittel AI, Epifanio CE (1990) Seasonal and tidal abundance of crab larvae in a tropical mangrove system, Gulf of Nicoya, Costa Rica. Mar Ecol Prog Ser 65:25-34

Dittel AI, Epifanio CE, Lizano O (1991) Flux of crab larvae in a mangrove creek in the Gulf of Nicoya, Costa Rica. Estuar Coast Shelf Sci 32:129-140

Drake P. Arias AM (1991) Ichthyoplankton of a shallow coastal inlet in south-west Spain: factors contributing to colonization and retention. Estuar Coast Shelf Sci 32 $347-364$

Feest J (1969) Morphophysiologische Untersuchungen zur Ontogenese und Fortpflanzungsbiologie von Uca annuLipes und Uca triangularls mit Vergleichsbefunden an Ilyoplax gangetica. Forma Functio 1:159-225

Forward RB Jr (1987) Larval release rhythms of decapod crustaceans: an overview. Bull Mar Sci 41:165-176

Little KT, Eplfanio CE (1991) Mechanism for the re-invasion of an estuary by two species of brachyuran megalopae. Mar Ecol Prog Ser 68:235-242

Manning RB, Holthuis LB (1981) West African brachyuran crabs (Crustacea: Decapoda). Smith Contrib Zool 306 $1-379$

Morgan SG, Christy JH (1995) Adaptive significance of the timing of larval release by crabs. Am Nat 145:457-479
Müller K (1983) Untersuchungen zur Populationsbiologie, Aktivitätsrhythmik und geographischen Verbreitung von Uca tangeri (Decapoda, Brachyura). Zool Jb Syst 110: $221-266$

Paula J (1985) The first zoeal stages of Polybius henslowi Leach, Maja squinado (Herbst), Pachygrapsus marmoratus (Fabricius) and Uca tangeri (Eydoux) (Crustacea, Decapoda, Brachyura). Arq Mus Bocage Ser B 2:137-147

Paula J (1989) Rhythms of larval release of decapod crustaceans in the Mira Estuary, Portugal. Mar Biol 100:309-312

Paula J (1993) Ecologia da fase larvar e recrutamento de crustáceos decápodes no estuário do rio Mira. PhD thesis, Universidade de Lisboa

Queiroga $\mathrm{H}$, Costlow JD, Moreira MH (1994) Larval abundance patterns of Carcinus maenas (Decapoda, Brachyura) in Canal de Mira (Ria de Aveiro, Portugal). Mar Ecol Prog Ser 111:63-72

Rodríguez A, Jones DA (1993) Larval development of Uca tangeri (Eydoux, 1835) (Decapoda: Ocypodidae) reared in the laboratory. J Crustacean Biol 13:309-321

Rodríguez A, Paula J (1993) Larval and postlarval development of the mud crab Panopeus africanus A. Milne Edwards (Decapoda: Xanthidae) reared in the laboratory. J Crustacean Biol 13:296-308

Salmon M, Seiple WH, Morgan SG (1986) Hatching rhythms of fiddler crabs and associated species at Beaufort, North Carolina. J Crustacean Biol 6:24-36

Sandifer PA (1975) The role of pelagic larvae in recruitment to populations of adult decapod crustaceans in the York River Estuary and adjacent lower Chesapeake Bay, Virginua. Estuar Coast Mar Sci 3:269-279

Wehrtmann IS, Dittel Al (1990) Utilization of floating mangrove leaves as a transport mechanism of estuarine organisms, with emphasis on decapod Crustacea. Mar Ecol Prog Ser 60:67-73

Wolfrath B (1992) Burrowing of the fiddler crab Uca tangeri in the Ria Formosa in Portugal and its influence on sediment structure. Mar Ecol Prog Ser 85:237-243

Zeng C, Naylor E (1996) Endogenous tidal rhythms of vertical migration in field collected zoea-1 larvae of the shore Carcinus maenas: implications for ebb tide offshore dispersal. Mar Ecol Prog Ser 132:71-82

Manuscript first received: November 21, 1996

Revised version accepted: February 3, 1997 